Vol. 28 No. 4, 2016

DOI:https: //doi.org/10.26725/JEE.2016.4.28.5764-5767

\title{
Improving the Participation of Tribal Women in Developmental Programmes
}

\section{R. Nisha ${ }^{1}$ and M. Asokhan ${ }^{2}$}

\begin{abstract}
Tribal women are gradually becoming integrated into village organizations. The present study was conducted among 120 tribal women respondents in four selected panchayats of Nilgiris district in Tamil Nadu. The respondents were selected using proportionate random sampling method. The data were collected from each respondent through a pre-tested interview schedule. The results were analysed with the help of statistical tools like mean, frequency and percentage. The results revealed that majority of the women respondents had more social taboos, superstitions and traditions as the major constraints in participating in various developmental programmes.
\end{abstract}

Keywords : Tribal women, Organizations, Motivation, Participation, The Nilgiris.

In the Indian context, the attributes of a tribal woman are that they live in relative isolation of hills and covered forests, and often in geographical areas inaccessible to the mainstream population. Tribes generally are groups which do not have a written letter or script. Their sense of history is shallow or mixed with mythology, and in terms of their cultural ethos, language, customs, institutions and beliefs; they stand out from other sections of society. The Government of India and State Governments, through the Ministry of Tribal Affairs and other agencies like the Planning Commission and Tribal Welfare Departments, through their schemes and programmes are focussing on improvements of living standards, education, health care and skill upgradation of these tribal people.

Tribal society is normally conceptualized as clan-lineage based segmentary system characterized by mechanical solidarity. Broadly, tribe is an aggregate of people sharing common social values, common dialect, territory and culture. But in a restricted sense, tribe means "a group of people under a chief and maintaining distinct cultural traits. Over eight per cent of India's total population, the tribals have a variety in their culture, lifestyle and above all different customs and worldview of their

1. Ph.D., Scholar and 2. Professor and Head, Department of Agri. Extension and Rural Sociology, Tamil Nadu Agricultural University, Coimbatore - 641003. 
own. Today, despite their adaptation and exposure to the culture of larger society, modernization, industrialization, they live in a world of dynamic isolation that helps the tribals to maintain their distinct socio-cultural identity. Many tribal development programmes are being implemented in the state of Tamil Nadu, wherein participation of tribal women is, in general, low compared to tribal men. The objective of the study was to find out the constraints and suggestions to increase the participation of tribal women in developmental programmes.

\section{METHODOLOGY}

This study focused on participation of tribal women in developmental programmes. In accordance with the objectives of the study, The Nilgiris district of Tamil Nadu was selected because it is one of the districts in Tamil Nadu where the percentage tribal population is higher. The Nilgiris District comprises four blocks viz., Udhagamandalam, Coonoor, Kotagiri and Gudalur. of these, Udhagamandalam and Kotagiri blocks were selected based on the high population of the tribals. From each block, four revenue villages were selected based on the tribal population and thus a total of eight revenue villages from two blocks were selected. Also, the familiarity of the researcher to the culture and local dialect of the district was considered during selection.

\section{FINDINGS AND DISCUSSION}

The tribal women expressed a variety of constraints \& suggestions for participation in department programmes (Table 1.)

Table 1.

Constraints expressed by Tribal Women

\begin{tabular}{|c|l|c|c|}
\hline $\begin{array}{c}|c| \\
\text { S1. } \\
\text { No. }\end{array}$ & \multicolumn{1}{|c|}{$(\mathrm{n}=120)^{*}$} \\
\hline 1. & Lack of adequate training facilities & No. & Percentage \\
\hline 2. & Lack of awareness about credit sources & 40 & 33.33 \\
\hline 3. & Insufficient credit facilities & 82 & 68.33 \\
\hline 4. & Indebtedness & 80 & 66.67 \\
\hline 5. & Less importance to actual needs & 81 & 67.50 \\
\hline 6. & More social taboos, superstitions and traditions & 100 & 83.33 \\
\hline 7. & Lack of adequate communication skills & 72 & 60.00 \\
\hline 8. & Inadequate motivation from family members & 60 & 50.00 \\
\hline 9. & Lack of periodical trainings & 34 & 28.33 \\
\hline 10. & Suppression due to “ dependancy” & 51 & 42.50 \\
\hline
\end{tabular}

* Multiple responses 
Among the problems faced, 83.33 per cent of tribal women had reported prevalence of social taboos, superstitions and traditions, followed by lack of awareness about credit sources (68.33\%), indebtedness (67.50\%) , insufficient credit facilities (66.67\%), and lack of awareness about the tribal development schemes (60.83\%). Inspite of several development programmes initiated by the Governments over the years, tribal women are hesitant to involve themselves in these programmes due to the restrictions imposed by the tribal society. The results of this study have confirmed this important problem which could be overcome primarily by ensuring education of tribal girls.

Table 2.

\section{Suggestions offered by the Tribal Women}

$$
(\mathrm{n}=120)^{*}
$$

\begin{tabular}{|c|l|c|c|}
\hline $\begin{array}{c}\text { S1. } \\
\text { No. }\end{array}$ & \multicolumn{1}{|c|}{ Suggestions } & No. & Percentage \\
\hline 1. & Training facilities & 100 & 83.33 \\
\hline 2. & Loan facilities & 85 & 70.83 \\
\hline 3. & Information on banking and marketing & 90 & 75.00 \\
\hline 4. & $\begin{array}{l}\text { Marketing facility for the products through } \\
\text { taluk and district centres }\end{array}$ & 80 & 66.67 \\
\hline 5. & $\begin{array}{l}\text { Awareness to be created on developmental } \\
\text { programmes and their importance }\end{array}$ & 79 & 65.83 \\
\hline 6. & $\begin{array}{l}\text { Counselling to be conducted periodically to } \\
\text { solve the problems faced by tribal women }\end{array}$ & 92 & 76.67 \\
\hline 7. & $\begin{array}{l}\text { Organizing exhibitions for displaying tribal } \\
\text { products }\end{array}$ & 80 & 66.67 \\
\hline 8. & $\begin{array}{l}\text { Purchase of products through government } \\
\text { sources }\end{array}$ & 82 & 68.33 \\
\hline
\end{tabular}

* Multiple responses

It is observed from the table that majority of the respondents had reported that training facilities should be provided to tribal women followed by counselling to be conducted periodically to solve the problems faced by tribal women and providing information on banking and marketing $(75.00 \%)$. If these suggestions are considered by the policy makers then the participation fo tribal women is likely to improve.

The results of the study had indicated that indebtness is widespread in the tribal areas and among the problems faced by the tribal women, it is probably the most difficult one to tackle. Further it was noted that these problems 
clearly indicate that in tribal areas, the tribal women are more bogged down by the constraints of customs and traditions and also their low economic status. Overcoming these constraints and considering their suggestions while formulating strategies would go a long way in empowerment of tribal women.

\section{REFERENCES}

Asokhan, M. (2006). Empowerment of Rural Women Through Self Help Groups - An Empirical Analysis.
Unpublished Ph.D. Thesis, AC\&RI, TNAU, Coimbatore.

Femina, P. (2003). Role of Voluntary Organizations in Empowering Women Through Self Help Groups. Unpublished M.Sc. (Ag.) Thesis, AC \& RI, TNAU, Coimbatore.

Sujeetha, T.N., Ravichandran, V., \& Karuna Jeba mary, M.V. (2015). Participation of self help group Tribal Women in Economic and social developmental activities. Journal of Extension Education, 27(1) 